ROCZNIKI TEOLOGICZNE

Tom LXVI, zeszyt 9 - 2019

DOI: http://dx.do.org/10.18290/rt.2019.66.9-4

ANDRZEJ GRECKI SVD

\title{
URZECZYWISTNIANIE KOŚCIOŁA W EKLEZJALNYCH WSPÓLNOTACH PODSTAWOWYCH W BRAZYLII
}

\author{
THE REALIZATION OF THE CHURCH \\ IN ECCLESIAL BASIC COMMUNITIES IN BRAZIL
}

\begin{abstract}
A b s t r a c t. Small communities are now a common phenomenon in Catholicism and other Christian denominations. Bearing this fact in mind, the author asks about their ecclesial nature on the example of the experience of Brazilian Basic Ecclesial Communities (Comunidades Eclesiais de Base - CEBs). We assume that the verification of the ecclesiality of these communities can be done by analyzing their genesis and development (part one) and the manifestations of their existence (part two). In the article we quote selected data from the history and life of the CEBs, which confirm that they are a phenomenon developing within the Church and in the communion with her. Through the CEBs, the Church is making herself realized and existentially visible, especially in environments that are responsive to the community dimension and the need to strengthen faith in conjunction with real personal, family and social challenges.
\end{abstract}

Key words: Ecclesiology; Fundamental Theology; Latin America; Small Communities.

Jednym z zagadnień teologii fundamentalnej jest rozpatrywanie wiarygodności Kościoła w przejawach jego życia. Pomimo zmian, które zaszły w tej dyscyplinie, w ostatnich dziesięcioleciach zadanie to nie straciło na znaczeniu. Jego aktualność potwierdza współczesna tendencja spojrzenia na wspólnotowe życie Kościoła, Jego urzeczywistnienie i obecność w małych grupach. Wymusza ona analizę i weryfikację tego zjawiska oraz spojrzenie na nie z punktu

Mgr lic. Andrzej GRECKI SVD - doktorant w Instytucie Teologii Fundamentalnej, Katolicki Uniwersytet Lubelski Jana Pawła II; adres do krespondencji - e-mail: agrecki@gmail.com 
widzenia doktryny o Kościele. Dlatego w niniejszym artykule zwróci się uwagę na potrzebę opisu popularnych dziś małych wspólnot katolickich jako przestrzeni urzeczywistniania się Kościoła, a tym samym weryfikacji ich eklezjalności. Dokona się tego na podstawie doświadczenia tzw. eklezjalnych wspólnot podstawowych (Comunidades Eclesiais de Base - dalej CEBs) w Brazylii. Podobnie jak inne, znane i popularne dziś, inicjatywy odnowy i towarzyszenia ludziom wierzącym, są one małymi jednostkami eklezjalnymi, które realizują wartości chrześcijańskie w sensotwórczej łączności z życiem. Zapoczątkowane jeszcze $\mathrm{w}$ połowie XX wieku, pomimo odmiennych losów i wykluczających się czasami interpretacji, nadal są uznaną przez episkopat brazylijski - $\mathrm{CNBB}^{1}$ i wartościową formą urzeczywistniania się Kościoła w tym kraju. XIV Kongres Intereklezjalny, odbywający się pod hasłem CEBs i wyzwania świata miejskiego, który miał miejsce w mieście Londrina w stanie Paraná w dniach 23-25 stycznia 2018 roku, świadczy o potencjale tych wspólnot, o wielorakich możliwościach życia Dobrą Nowiną we wspólnocie Kościoła i w złożonej sytuacji społecznej Brazylii. Papież Franciszek w przesłaniu na ten kongres zachęca, aby CEBs były narzędziem ewangelizacji i promocji osoby ludzkiej zdolnym do stawienia czoła współczesnej kulturze odrzucenia $^{2}$.

\section{EKLEZJALNO-SPOŁECZNA GENEZA CEBs}

Trudno jest dokładnie określić, kiedy nastąpił początek CEBs. Można jedynie orientacyjnie wskazać, jak wspomniano, na lata pięćdziesiąte XX wieku. Już za czasów Piusa XI i jego następcy, Piusa XII zachodziły istotne reformy w Kościele powszechnym: w obszarze sposobów działań pastoralnych, liturgii, katechezy, egzegezy i teologii. Wtedy też zapoczątkował działalność w nowej formie wspomniany już episkopat Brazylii - CNBB (1952). Instytucja ta stała się narzędziem wzmacniającym wdrażanie reform, których

\footnotetext{
${ }^{1}$ CNBB - Conferência Nacional dos Bispos do Brasil.

${ }^{2}$ FRANCISZEK, Carta do Papa Francisco ao participantes no $13^{\circ}$ Encontro Intereclesial das CEBs. 17.12.2014: http://w2.vatican.va/content/ francesco/pt/letters/2013/documents/papafrancesco_20131217_comunita-ecclesiali-base.html (dostęp: 22.01.2019); TENŻE, Carta do Papa Francisco aos participantes do XIV Encontro Intereclesial das CEBs. 24.01.2014: http://www. cnbb.org.br/as-cebs-possam-ser-um-instrumento-de-evangelizacao-e-de-promocao-da-pessoa-hu mana-deseja-o-papa-francisco-em-mensagem-enviada-ao-14o-intereclesial/(dostęp:22.01.2019).
} 
owocem był wzrost świadomości wiary, roli chrześcijaństwa w życiu osobistym i kształtowania rzeczywistości społecznej ${ }^{3}$.

Powstanie CEBs to nie tylko projekty odnowy życia wiarą, ale także zmiana mentalności duchownych i świeckich, zwłaszcza stosunku do ludności prostej i często ubogiej, która stanowiła wówczas ok. dwóch trzecich społeczeństwa brazylijskiego. Jeszcze w latach trzydziestych XX wieku, w okresie przebudzenia politycznego niższych warstw społecznych, model działań duszpasterskich odzwierciedlał bardziej potrzeby duchowe klas średnich i wpływowych elit. Dominowało przekonanie, że zadaniem Kościoła w kwestii pracy na rzecz ubogich jest podtrzymanie pobożności i religijności ludowej oraz organizacja pomocy charytatywnej. Czuwano także nad porządkiem moralnym i wprowadzeniem katolickich zasad życia społecznego poprzez uświadamiającą ewangelizację grup rządzących, osób majętnych i świata kultury. Chociaż taka strategia nie była pozbawiona racji, jej elitaryzm doprowadził do znacznego oddalenia się Kościoła od uboższych warstw społecznych. Problem ten został dostrzeżony w latach pięćdziesiątych XX wieku. Wówczas rozpoczął się proces ponownego zbliżania do tych grup oraz ich upodmiotowienia, nie zapominano jednocześnie o elitach. W tym zbliżeniu ważną rolę odegrały inicjatywy pastoralne aktywizujące małe grupy zorganizowane wokół kaplic wiejskich oraz w ubogich peryferiach rozrastających się gwałtownie miast. Dzięki nim Kościół mógł łatwiej dotrzeć do klasy robotniczej i grup do niej zbliżonych (infiltrowanych także przez ideologie lewicowe i komunistyczne) ${ }^{4}$.

Jednym ze sposobów zaznaczenia obecności Kościoła w uboższych warstwach było tworzenie mechanizmów i organizacji starających się uaktywnić oraz rozwinąc ludzi religijnie i społecznie. Z czasem takie starania doprowadziły do modyfikacji dotychczasowego modelu pastoralnego, który zdawał się służyć, według ówczesnych diagnoz, głównie państwu i elitom. Nie wykluczając tych grup, nastapiło przesunięcie akcentu w kierunku społecznie wykluczonych klas ubogich pracujących i bezrobotnych oraz narodu rozumianego jako całość. Dzięki nowo powstałej mentalności budowania wspólnoty, uzasadnionej ówczesnym nauczaniem Kościoła i rozwijającą się prężnie teologią, nieznaczące i marginalne dotychczas grupy stawały się świadomym podmio-

\footnotetext{
${ }^{3}$ A. BALDISSERA, CEBs: poder, nova sociedade, Paulinas, São Paulo 1988, s. 12-16.

${ }^{4}$ E. Hoornaert, Comunidades de Base: dez anos de experiência, REB (Revista Eclesiástica Brasileira), 1978, 38, s. 482-484; H.C.J. de MATOS, CEBs uma interpelação para o ser Cristão hoje, Loyola, São Paulo 1985, s. 23-25.
} 
tem wiary i życia eklezjalnego oraz świadomymi swoich praw i obowiązków obywatelami ${ }^{5}$.

W powstaniu CEBs ważną rolę odegrały te organizacje, które widziały konieczność zaangażowania i odpowiedzialności za życie społeczne. Na czoło wysunęły się przede wszystkim Ruch Edukacji Podstawowej (Movimento Educação de Base) i Akcja Katolicka (Ação Católica). Ukierunkowanie działań na upodmiotowienie, rozwój wiedzy, kompetencji i umiejętności ludzi z klas zdecydowanej większości społeczeństwa, a nie jedynie elit, pozwoliło odkryć potencjał tkwiący w laikacie ${ }^{6}$.

Chociaż wspomniane wyżej kwestie i ruchy tworzą ważne tło powstania CEBs, ich geneza i rozwój wiążą się przede wszystkim z planami pastoralnymi episkopatu brazylijskiego. Już od 1962 roku uwzględniały one czynniki formacyjne i prowspólnotowe różnych grup społecznych, zwłaszcza ubogich i żyjących na marginesie życia społecznego. Pozytywnym skutkiem takiego ukierunkowania działań była odnowa parafii, instytucji kościelnych i sposobów ich obecności w życiu społeczno-politycznym. Systematyczne i planowe działania Kościoła spełniały pionierskie zadanie adaptacji modeli działań i struktur eklezjalnych do wymagań Ewangelii i czasów współczesnych. Były i nadal pozostają krokiem w kierunku zbliżenia wiernych świeckich i Kościoła hierarchicznego ${ }^{7}$.

Przejawem urzeczywistniania się Kościoła w CEBs i świadkiem ich rozwoju są kongresy intereklezjalne (Encontros Intereclesiais das CEBs). Ta cykliczna forma zjazdów - w latach 1970-2018 odbyło się ich 14 - jest przykładem spotkania się wiary chrześcijańskiej z problemami przeżywanymi przez wspólnoty i w ogóle społeczeństwo brazylijskie. Poruszano na nich takie kwestie, jak: odnowa Kościoła w wierze narodu, pielgrzymujący lud Boży i jego rola w Kościele i państwie, ucisk i wyzwolenie, Kościół i lud

${ }^{5}$ F.L.C. TEIXEIRA, A gênese das CEBS no Brasil - elementos explicativos, Paulinas, São Paulo 1988, s. 31-32; M. AzEVEdo, Comunidades Eclesiais de Base e Inculturação da Fé, Loyola, São Paulo 1986, s. 39; A. BALDISSERA, CEBs: poder, s. 62-63; L. BofF, O caminhar da Igreja com os oprimidos, Vozes, São Paulo 1988, s. 62-65; F. BETTO, As CEBs como petencial de transformação da Sociedade Brasileira, REB 1983, 43, s. 494-495.

${ }^{6}$ F. TeIXeIRa, A gênese das CEBS, s. 79-99; H. MATOS, CEBs uma interpelação, s. 18; J.O. BeOzzo, História da Igreja no Brasil, Vozes, São Paulo 1984, s. 474; E. HoORnAERT, O Futuro das CEBs, REB 1991, 51, s. 161-163.

${ }^{7}$ W 1962 roku CNBB wydała Plano de Emergência, który zapoczątkował trwającą do dziś praktykę planowania pastoralnego dla całego Kościoła w Brazylii. Od 1972 roku, co cztery lata, biskupi ustalają wspólny plan działań. Więcej na ten temat: Conferência Nacional dos Bispos do Brasil (CNBB), http://www.cnbb.org.br (dostęp: 28.01.2019); M. LEARATO, CEBs. Gente que se faz gente na Igreja, Loyola, São Paulo 1988, s. 21. 
zaczynem nowego społeczeństwa, kultura grup uciśnionych i marginalizowanych, nadzieja chrześcijańska, duchowość i wyzwania w nowym tysiącleciu, ekologia, sprawiedliwość i pokój w służbie życiu, wyzwania współczesnych środowisk miejskich.

Planowe działania duchownych i liderów świeckich w Brazylii, wspierające ruch małych wspólnot, są przykładem urzeczywistniania się Kościoła w konkretnych uwarunkowaniach społeczno-kulturowych. Dokonywało się ono w ramach ustaleń Soboru Watykańskiego II, nauczania papieskiego oraz decyzji podejmowanych przez episkopat latynoamerykański na konferencjach w Medellín (1968), Puebla (1979), Santo Domingo (1992) i Aparecida (2007). Nacisk na życie wspólnotowe, oparte na komunii i obecności w Kościele również osób ubogich i marginalizowanych, wzmacniał CEBs, podmiotowość i misję świeckich. Plany pastoralne otworzyły nowe pola działań, w których praktyczne zastosowania znajdowała doktryna katolicka ${ }^{8}$.

\section{ECCLESIA U PODSTAW}

Zarysowana powyżej geneza eklezjalnych wspólnot podstawowych dowodzi, że od samych początków eklezjalność jest kluczowym wymiarem tożsamości CEBs. W stosunku do tej nowej wspólnotowej formy życia chrześcijańskiego sprawdzają się słowa Pawła VI z Evangelii nuntiandi: „rodzą się z potrzeby gorliwego życia życiem Kościoła albo z pragnienia i poszukiwania bardziej ludzkiego sposobu życia, o co trudno w dużych wspólnotach kościelnych, szczególnie w wielkich dzisiejszych miastach, gdzie żyje się gromadnie i jakby anonimowo" (EN 58). Przytoczone dane związane z genezą CEBs, wsparte słowami papieża, upoważniają do wniosku, że Kościół jest kluczowym środowiskiem ich narodzin i życia. Działając zawsze w jakiejś parafii, widzą siebie jako cząstkę Kościoła lokalnego i powszechnego. Żyjąc Ewangelią i we wspólnocie Kościoła, CEBs są miejscem doświadczenia perspektywy zbawienia i wyzwolenia w świecie naznaczonym grzechem, w oczekiwaniu na ostateczne dopełnienie się historii w Bogu'

\footnotetext{
${ }^{8}$ G.F. QueIRoga, CNBB: Comunicação e co-responsabilidade, Paulinas, São Paulo 1975, s. 370-371; F. TEIXEIRA, A gênese das CEBS, s. 120; V. CODINA, Eclesiologia Latino-Americana da Libertação, REB 1982, 42, s. 64-65.

${ }^{9}$ F. TeIXEIRA, A gênese das CEBS, s. 113-114; L. BofF, Eclesiogenese. As Comunidades Eclesiais de Base reinventam a Igreja, Vozes, Petrópolis 1977, s. 36, 81; C. Floristan, Povo de Deus e teologia Crista, REB 1985, 45, s. 302-306.
} 
Eklezjalność CEBs dokonuje się w codzienności życia podstawowych klas społecznych, będących „u podstaw” ewangelizacji skierowanej do ubogich i spragnionych wiary. To sprawia, że Kościół ze swoim przesłaniem ma możliwość inkulturowania wiary w świat indywidualnych, rodzinnych i wspólnotowych problemów przeżywanych w kontekście kultury i pobożności wielu ludzi. Jest to Kościół będący pośród ludu, wrażliwy na jego sprawy, co czyni go zrozumiałym, prostszym i ewangelicznym. W ten sposób realizowana jest preferencyjna opcja Kościoła na rzecz ubogich, która daje ludziom ubogim możliwość wielowymiarowego wzrostu we wspólnocie eklezjalnej. Jest okazją, aby zwykły i często zagubiony człowiek dzięki wspólnocie stał się ludem Bożym, a Kościół spełniając swoją misję, odnalazł się w świecie ubogich. W CEBs rozwiązuje się problemy, które często mają wspólne cechy, ponieważ ludzie żyją w nich w bliskości geograficznej, kulturalnej, w pokrewieństwie, mówią tym samym językiem, maja podobny światopogląd i plany życiowe oraz doświadczają wspólnego losu w czasie i przestrzeni. Są to wyjątkowe przestrzenie, dzięki którym Kościół ma szansę uobecnić się ${ }^{10}$.

Jako ideał wewnętrznego życia CEBs i relacji z otaczającym światem przedstawia się misterium Trójcy Świętej. Pragnienie uobecniania w CEBs wspólnoty, wzorem koinonii Boga-Syna-Ducha, pokazuje ich eklezjalny charakter. W przypadku CEBs nie można zatem mówić jedynie o wspólnocie socjologicznej, ale także o teologicznej. Taki rodzaj wspólnoty, w którym dąży się do urzeczywistnienia ideałów trynitarnych, przynależy bardziej do planu duchowego o inspiracji chrześcijańskiej, niż do projektu czysto ludzkiego, zamkniętego we własnej immanencji. CEBs ze swoją trynitarną duchowością są zatem znakiem przynależności do Boga, wspólnotami wezwanymi do tego, aby być w historii obrazem misterium Boga oraz pielgrzymującego nowego ludu Bożego ${ }^{11}$.

Wspólnota i jej członkowie, żyjąc Chrystusem, wchodzą w relacje z innymi oparte na jedności i współuczestnictwie oraz na pozostałych wartościach ewangelicznych. Identyfikują się z posłaniem Jezusa i Jego misją w służbie zbawienia własnego i innych. Są świadkami Ducha Świętego w społeczeństwie i historii. Stąd realizacja ideału wspólnoty eklezjalnej i troska o zbawie-

${ }^{10}$ C. BofF, Crónica teologica do V Encontro Intereclesial de Comunidades de Base, REB 171, 1983, s. 478; D.L. FERnANDES, A educação do povo nas CEBs, w: Isto não se aprende na escola, red, L. M. Duarte, Petrópolis 1983, s. 44; A. BALDISSERA, CEBs: poder, s. 71-72.

${ }^{11}$ M. Learato, CEBs. Gente que se faz gente, s. 11-113. 
nie są nierozłączne. Bycie zbawionym oznacza tworzenie $\mathrm{z}$ innymi jednej owczarni Wiecznego Pasterza ${ }^{12}$.

Członkowie CEBs uważają swoje wspólnoty za eklezjalne, ponieważ kierując się przykładem Jezusa Chrystusa i pierwszej gminy chrześcijańskiej w Jerozolimie, dążą one do urzeczywistniania ewangelicznej braterskiej solidarności. Taki projekt życia nie ogranicza się tylko do dzielenia tych samych uczuć, światopoglądu i wzajemnej solidarności. W grę wchodzi przede wszystkim obopólne inspirowanie swego życia oraz dzielenie się wiarą, miłością i nadzieją. Te walory codziennie przekładają się na styl życia, wartości, wzorce zachowań, życie liturgiczno-modlitewne i formację chrześcijańską. Uczestnikami tych dóbr duchowych i ich owoców stają się wszyscy członkowie wspólnoty, także ubodzy i wykluczeni. Tym samym słowa: „Trwali oni w nauce Apostołów i we wspólnocie, w łamaniu chleba i w modlitwach" (Dz 2,42), stają się także cechą i znakiem tożsamości CEBs ${ }^{13}$.

W życiu CEBs należy podkreślić także szczególne miejsce Pisma Świętego. Jego obecność w życiu wspólnoty i jej członków jest cechą wyróżniającą. Słowo Boże, czytane i rozważane we wspólnocie oraz indywidualnie, wyznacza sposób życia oraz rozumienia zachodzących wydarzeń, zarówno osobistych, jak i społecznych. Słuchanie Słowa Bożego jest czynnością wspomagającą powstanie wiary i jej rozwój, realizującą się w postawie ucznia podążającego za Chrystusem. W konsekwencji Słowo Boże tworzy i umacnia wspólnotę eklezjalną i jej członków - pielgrzymujący lud Boży w historii. CEBs stwarzają więc możliwości ziszczenia zamiarów Jezusa: zgromadzenie wszystkich ludów oraz pełne i definitywne ich zbawienie. Niektórzy teolodzy, jak Leonardo Boff czy Henrique Matos, są zdania, że w naszych czasach CEBs potwierdzają aktualność proklamowanego przez Jezusa Królestwa Bożego. Dziś wkracza ono w historię ludzkości także w takich małych wspólnotach. Przez nawrócenie osobiste i wspólnotowe, przyjęcie Dobrej Nowiny oraz świadectwo, Bóg króluje w historii i jest obecny pośród pielgrzymującego ludu Bożego ${ }^{14}$.

Wiara Kościoła jest fundamentem życia chrześcijańskiego. Ta zasada obowiązuje także w CEBs. Na niej opierają się wszelkie relacje wspólnotowe

\footnotetext{
${ }^{12}$ Konstytucja dogmatyczna o Kosciele, nr 9, w: J. GoBLICKI, E. FloRKOWSKI, K. WOJTYŁA, Sobór Watykański II. Konstytucje, dekrety, deklaracje. Tekst polski, Pallottinum, Poznań 1986.

13 A. BARreiro, A eclesialidade das CEBs, REB 1986, nr 46, s. 634-635; P.C. Cipolini, A identidade da Igreja na América Latina, Vozes, São Paulo 1987, s. 124-125.

${ }^{14}$ L. BoFf, O caminhar da Igreja, s. 313-315; H. MATOS, CEBs uma interpelação, s. 154-157.
} 
i misja. Członkowie wspólnot wierząc, stają wobec Boga, a dzięki temu łączą się z braćmi i otaczającym światem. Od Boga-Człowieka otrzymują życiodajne sakramenty, czują się wezwani do różnych posług we wspólnocie, która cała jest apostolska i ministerialna. Jednakże wiara nie określa tylko otrzymywania dobra i relacji, ale tworzy wspólnotę eklezjalną. Biskupi latynoamerykańscy już na konferencji w Medellín (1968) podkreślali, że CEBs definiując się poprzez wiarę w Jezusa Chrystusa, są wspólnotami wiary - communitas fidelium. Według dokumentu tam powstałego, wspólnota jest oznaką przyjścia Królestwa Bożego, a zarazem instrumentem tego Królestwa w świecie. Jest widzialnym znakiem, jak też instrumentem wyzwolenia i zbawienia w Królestwie Bożym ${ }^{15}$.

W CEBs wiara nie jest oderwaną od życia lub alienującą ideą. Wspólnota, która wyznaje wiarę w Jezusa Chrystusa, nie jest tylko schronieniem dla zalęknionych, zagubionych lub zawiedzionych niedoskonałością, czy też złem tego świata. Przyjęta Ewangelia przemienia sposób myślenia i życia członków wspólnot. Czesto wyrażają oni opinię, iż należy ulokować Ewangelię w ich życiu, a ich życie - w Ewangelii. Z tej wzajemnej konfrontacji pomiędzy Ewangelią a życiem rodzi się nowy wymiar pozwalający na przeciwdziałanie grzechom osobistym i społecznym wyrażającym się w bolesnych niesprawiedliwościach, przemocy i braku jedności. Wiara rodząca się w CEBs, w drodze do ostatecznego spełnienia się w Bogu, stawia czoło siłom przeciwnym Jego panowaniu. Rezultatem wzajemnego przenikania się wiary i życia jest decyzja o naśladowaniu Chrystusa. To oznacza akceptację jego Osoby poprzez wiarę, stanie się jego świadkiem, aż po męczeństwo ${ }^{16}$.

Warto również podkreślić, że cechą uobecniająca Kościół, związaną z ewangeliczną wiarą CEBs, jest chrześcijańska nadzieja i wypływająca z niej radość. Każdy, kto się nawróci i przylgnie prawdziwie do Ewangelii, kto znajdzie „droga perłę”, ,ukryty skarb”, jest przepełniony niezmierzoną i promieniującą radością (por. Mt 13,44-45; Łk 15,5-7.9-10.32). Cała wspólnota,

\footnotetext{
15 II CONFERÊNCIA GERAL DO EPISCOPADO LATINO-AMERICANO, A Igreja na autal transformação da America Latina. Petrópolis, cz. II, III i XV, Medellín 1969; H. MATos, CEBs uma interpelação, s. 154-157; F. TEIXEIRA, A gênese das CEBS, s. 290-294; K. KELER, Eklezjalny charakter Wspólnot Podstawowych wedtug Leonarda Boffa, „Collectanea Theologica” 54(1984), nr 3, s. 44-46.

16 A. Barreiro, A eclesialidade das CEBs, s. 642-643; F. BetTo, CEBs: rumo a nova sociedade, Loyola, São Paulo 1988; TENŻE, As CEBs como petencial de transformação da Sociedade Brasileira, REB 1983, 43, s. 494-503.
} 
która przyjmie Ewangelię jako Dobrą Nowinę o zbawieniu, żyje głęboką nadzieją i radością mimo różnych prób, przez które przechodzi ${ }^{17}$.

Te ewangeliczne wartości, obecne w historii Kościoła powszechnego, począwszy od gmin Nowego Testamentu, uobecniają się także w CEBs. „Radość i prostota serca" jest wyróżniającą cechą charakteryzującą pierwsze gminy chrześcijańskie (por. Dz 2,46). Również CEBs są włączone w tę prostą i spontaniczną radość. Podobnie jak radość pierwszych gmin, radość Wspólnot Podstawowych wypływa z wiary. Powodowana jest wzajemnym dzieleniem się komunią z Bogiem i braćmi, życiem we wspólnocie, formowaniem braterstwa. Stąd też wszystkie formy uczestnictwa sprawiają radość, czy to w czasie modlitwy, czy podczas nabożeństw, czy przy wykonywaniu prac wspólnotowych. Tutaj chrześcijanie czują radość nawet podczas prześladowań i prób. Wierzą, że cierpią za ideę sprawiedliwości Królestwa Bożego, za sprawę Ewangelii Jezusa, za sprawę zbawczego planu Ojca. Wówczas radości z wiary, która daje im tę pewność, nikt im nie może odebrać ${ }^{18}$.

W CEBs przejawia się także apostolskość Kościoła. W Tradycji przyjmuje się, że jest to jedno z jego głównych znamion. W sensie węższym apostolskość powiązana jest $\mathrm{z}$ Apostołami i ich następcami (biskupami), a w szerszym - z całym Kościołem. W drugim znaczeniu apostolskość obejmuje tych, którzy wyznają wiarę Apostołów, poprzez którą poznaje się, że Jezus nie jest jedynie prorokiem, który przeszedł pośród nas, potężny w słowie i czynie, ale jest Synem Bożym - Zbawicielem. Apostolskość dotyczy też tych, którzy są powołani do życia apostolskiego poprzez naśladowanie Jezusa Chrystusa oraz do pełnienia szczególnej misji w czasach Kościoła. Odnosi się również do wszystkich wiernych, ponieważ każdy jest odpowiedzialny za jedność Kościoła tak, jak apostołowie w pierwotnym Kościele ${ }^{19}$.

W CEBs zauważa się istotną cechę Kościoła: łączność ze swoimi pasterzami, która nabiera misyjnego dynamizmu poprzez ewangelizację oraz tworzenie nowych wspólnot. Tworzą się one w jedności z innymi wspólnotami i z Kościołem. Swoją eklezjalność realizują troszcząc się o jedność i o towarzyszenie im hierarchii Kościoła. W takich wspólnotach, poza powszechnie znanymi funkcjami i sposobami ich realizacji, biskupi stają się pasterzami jedności, ewangelicznej dynamiki, wspierającej lud obecnością Kościoła powszechnego. Są pasterzami, którzy kroczą ze wspólnotą i ją prowadzą. Ich posługa jest

\footnotetext{
${ }^{17}$ M. Learato, CEBs. Gente que se faz gente, s. 54-56.

18 A. BARreiro, A eclesialidade das CEBs, s. 639.

${ }^{19}$ L. Boff, Eclesiogenese. As Comunidades Eclesiais de Base reinventam a Igreja, Vozes, Petrópolis 1977, s. 37.
} 
postrzegana przez członków CEBs jako dar, który umacnia i daje impuls do wzrostu osobistego i wspólnotowego, bez „gaszenia” twórczości i uczestnictwa ludzi w Kościele i społeczności ${ }^{20}$.

CEBs żyją także w ścisłej łączności z kapłanami. Poprzez swoją obecność we wspólnocie, życie sakramentalno-liturgiczne, zwyczajowe i nowe formy pobożności, formację religijną i ogólnoludzką, kapłani stają się konsekrowanymi braćmi w wierze, którzy dynamizują i uaktywniają potencjał wspólnoty, są doradcami i przyjaciółmi, ogniwami jedności wspólnoty z biskupem. Sa towarzyszami wspólnej drogi kroczącymi razem ze wspólnotą, są obecni w istotnych momentach jej życia, zarówno tych specyficznie kościelnych, takich jak modlitwa, liturgia Słowa, sakramenty, jak i kulturalnych oraz społecznych: święta, spotkania, wzajemna pomoc i wspólne zaangażowanie w przemianę warunków społecznych ${ }^{21}$.

Ponad pięćdziesięcioletnia historia CEBs pokazuje, że są one ważne także dla osób konsekrowanych - uczestników życia zakonnego. Zakonnicy i zakonnice w żywym spotkaniu ze wspólnotami odkrywają różne formy apostolstwa, a także solidarności z ubogimi. Ich działalność na rzecz CEBs, indywidualna i wspólnotowa, wyróżnia się obecnością - wejściem (port. inserção - insercja) w świat zwykłych ludzi, często ubogich. W ten sposób otwieraja się szerokie możliwości towarzyszenia im oraz działań na rzecz ich rozwoju i ewangelizacji. Asystują wspólnotom, obdarzając je „mistyką miłości”, zaufaniem i służą, prowadząc do nawrócenia i wyzwolenia. Wielu z nich, realizując radykalną opcję na rzecz ubogich, przebywa $z$ nimi, wchodzi w ich świat pracy i dzieli ich styl życia. Biskupi w Puebla określili taką opcję jako „tendencję najbardziej zauważalną w życiu zakonnym Ameryki Łacińskiej”"22.

Przedstawione wyżej wybrane przejawy życia CEBs wykazały szereg faktów potwierdzających ich fundamentalny związek z Kościołem. Wskazano, że są one miejscem, w którym Kościół staje się ich urzeczywistnieniem. W spo-

\footnotetext{
${ }^{20}$ F. Betto, Rumo, CEBs 1988, s. 43; C. BofF, Crónica teologica do V Encontro, s. 487.

${ }^{21}$ D.L. Fernandes, Comunidades Eclesiais de Base e pastoral de conjunto, Vozes, São Paulo 1985, s. 78.

22 III Conferência Geral do Episcopado Latino-Americano. Puebla, Evangelização no presente e no futuro da América Latina, Vozes, São Paulo 1986, s. 52; J.B. LiBÂNIO, As grandes ropturas socio-culutrais e eclesiais, Petrópolis 1985, s. 166-167, 176-179.
} 
leczeństwie, gdzie nastąpiło ogromne zindywidualizowanie współżycia ludzkiego, podstawowym zadaniem stało sie tworzenie grup, które w miarę możliwości potrafiłyby odnaleźć miejsce na rzeczywisty dialog i solidarność międzyludzką.

Powstawanie małych wspólnot nadaje nowe oblicze Kościołowi. Jest to Kościół obecny i urzeczywistniający się w Ludzie Bożym, wrażliwy na ludzką rzeczywistość, co czyni go prostszym i bardziej ewangelicznym.

Omówiona kwestia, chociaż wymaga poszerzenia i dalszych studiów, pokazuje możliwości różnorodnych sposobów weryfikacji eklezjalności tych wspólnot i przeżywania ich wiary. CEBs, podobnie jak wiele innych znanych dziś inicjatyw życia w małych wspólnotach, aby były chrześcijańskie i katolickie muszą kierować się kryteriami zaczerpniętymi z Ewangelii i wypracowanymi przez Tradycję Apostolską. Dlatego, aby zachować tożsamość eklezjalną, konieczne są dalsze studia o CEBs i o podobnych zjawiskach w Kościele powszechnym.

\section{BIBLIOGRAFIA}

Azevedo M., Comunidades Eclesiais de Base e Inculturação da Fé, Loyola, São Paulo 1986. BAldissera A., CEBs: poder, nova sociedade, Paulinas, São Paulo 1988.

BARreiro A., A eclesialidade das CEBs, REB 1986, nr 46, s. 631-649.

BeOzzo J.O., História da Igreja no Brasil, Vozes, São Paulo 1984.

BetTo F., CEBs: rumo a nova sociedade, Loyola, São Paulo 1988.

Betto F., As CEBs como petencial de transformação da Sociedade Brasileira, REB 1983, nr 43, s. 494-503.

Boff C., Crónica teologica do V Encontro Intereclesial de Comunidades de Base, REB 1983, 171.

Boff L., Eclesiogenese. As Comunidades Eclesiais de Base reinventam a Igreja, Petrópolis 1977.

BofF L., O caminhar da Igreja com os oprimidos, Vozes, São Paulo 1988.

Cipolini P.C., A identidade da Igreja na América Latina, Vozes, São Paulo 1987.

Codina V., Eclesiologia Latino-Americana da Libertação, REB 1982, nr 42, s. 61-81.

CONFERÊNCIA NACIONAL DOS BISPOS DO BRASIL (CNBB), http://www.cnbb.org.br (dostęp: 28.01.2019).

II CONFERÊNCIA GERAL Do EPISCOPADo LATINO-AMERICANO. A Igreja na autal transformação da America Latina. Medellín, Petrópolis 1969.

III CONFERÊNCIA GERAL DO EPISCOPADO LATINO-AMERICANO. Evangelização no presente e no futuro da América Latina. Puebla, Vozes, São Paulo 1986.

MAtos de H.C.J., CEBs uma interpelação para o ser Cristão hoje, Loyola, São Paulo 1985.

FERNANDES D.L., A educação do povo nas CEBs, w: Isto não se aprende na escola, red. L.M. Duarte, Petrópolis 1983, s. 21-55. 
Fernandes D.L., Comunidades Eclesiais de Base e pastoral de conjunto, Vozes, São Paulo 1985.

Floristan C., Povo de Deus e teologia Crista, REB 1985, nr 45, s. 296-309.

FRANCISZEK, Carta do Papa Francisco ao participantes no $13^{\circ}$ Encontro Intereclesial das CEBs. 17.12.2014: http://w2.vatican.va/content/francesco/pt/letters/2013/documents/papa-francesco_20131217_comunita-ecclesiali-base. html (dostęp: 22.01.2019).

FrancISZEK, Carta do Papa Francisco aos participantes do XIV Encontro Intereclesial das CEBs. 24.01.2014: http://www.cnbb.org.br/as-cebs-possam-ser-um-instrumento-de-evangelizacao-e-de-promocao-da-pessoa-humana-deseja-o-papa-francisco-em-mensagem-enviada-ao14o-intereclesial/ (dostęp: 22.01. 2019).

Hoornaert E., Comunidades de Base: dez anos de experiência, REB 1978, nr 38, s. 474-502.

HoORnAert E., O Futuro das CEBs, REB 1991, nr 51, s. 161-163.

KELER K., Eklezjalny charakter Wspólnot Podstawowych według Leonarda Boffa, „Collectanea Theologica" 54(1984), nr 3, s. 39-54.

Konstytucja dogmatyczna o Kościele, 9, w: J. Goblicki, E. Florkowski, K. WoJtYŁA, Sobór Watykański II. Konstytucje, dekrety, deklaracje. Tekst polski, Pallottinum, Poznań 1986.

Learato M., CEBs. Gente que se faz gente na Igreja, Loyola, São Paulo 1988.

LiBÂNIO J.B., As grandes ropturas socio-culutrais e eclesiais, Petrópolis 1985.

QueIRoga G.F., CNBB: Comunicação e co-responsabilidade, Paulinas, São Paulo 1975.

TeIXeIRA F.L.C., A gênese das CEBS no Brasil - elementos explicativos, Paulinas, São Paulo 1988.

\section{URZECZYWISTNIANIE KOŚCIOŁA \\ W EKLEZJALNYCH WSPÓLNOTACH PODSTAWOWYCH W BRAZYLII}

St res z c z e n i e

Małe wspólnoty stały się masową formą życia chrześcijańskiego w katolicyzmie i w innych wyznaniach chrześcijańskich. Wychodząc od tak powszechnego zjawiska, autor analizuje wybrane aspekty urzeczywistniania się Kościoła na przykładzie doświadczenia brazylijskich wspólnot podstawowych (Comunidades Eclesiais de Base - CEBs). Zagadnienie rozwija w dwóch częściach. W pierwszej omawia ich genezę, w drugiej - przejawy życia CEBs jako formy stawania się Kościoła na poziomie pierwotnych grup społecznych.

Słowa kluczowe: Eklezjologia; Teologia Fundamentalna; Ameryka Łacińska; małe wspólnoty. 